BASINDO : Jurnal Kajian Bahasa, Sastra Indonesia, dan Pembelajarannya

Volume 2 Nomor 1, 2018

Journal homepage : http://journal2.um.ac.id/index.php/basindo

\title{
KUALITAS SOAL UJIAN AKHIR SEMESTER I MATA PELAJARAN BAHASA INDONESIA KELAS XII
}

\author{
Gustiana Putri*, Endah Tri Priyatni, Titik Harsiati \\ Universitas Negeri Malang, Indonesia
}

\begin{tabular}{|c|c|}
\hline A R T ICLE I N F O & A B S T R A C T \\
\hline $\begin{array}{l}\text { Keyword: } \\
\text { kualitas, } \\
\text { validitas isi, } \\
\text { validitas konstruk, } \\
\text { ketepatan, } \\
\text { dan soal ujian akhir semester }\end{array}$ & $\begin{array}{l}\text { Tujuan penelitian ini untuk mendeskripsikan kualitas soal ujian akhir semester I Mata } \\
\text { Pelajaran Bahasa Indonesia kelas XII dari segi validitas isi, validitas konstruk, dan } \\
\text { ketepatan berdasarkan kaidah penulisan soal pilihan ganda. Penelitian ini menggunakan } \\
\text { pendekatan evaluatif. Data penelitian berupa kisi-kisi soal dan soal ujian akhir semester I } \\
\text { Mata Pelajaran Bahasa Indonesia kelas XII. Pengumpulan data dilakukan dengan teknik } \\
\text { dokumentasi. Hasil penelitian menunjukkan bahwa soal ujian akhir semester I Mata } \\
\text { Pelajaran Bahasa Indonesia kelas XII memiliki kualitas lumayan tinggi dari segi } \\
\text { validitas isi, validitas konstruk, dan ketepatan berdasarkan kaidah penulisan soal pilihan } \\
\text { ganda. }\end{array}$ \\
\hline
\end{tabular}

\section{PENDAHULUAN}

Penilaian adalah kegiatan menafsirkan atau mendeskripsikan hasil pengukuran. Tujuan penilaian dalam dunia pendidikan untuk mengetahui pemahaman siswa terhadap materi-materi yang telah dipelajari. Pada tahun ajaran baru 2013 pemerintah menyempurnakan Kurikulum Tingkat Satuan Pendidikan (KTSP) menjadi Kurikulum 2013. Berdasarkan Permendikbud Nomor 81A (2013:25-26) dinyatakan bahwa karakteristik penilaian dalam kurikulum 2013 adalah belajar tuntas, otentik, berkesinambungan, berdasarkan acuan kriteria, dan menggunakan teknik penilaian yang bervariasi. Senada dengan pendapat Sutomo (1984:48-50) menyatakan bahwa jenis-jenis kriteria bagi tes yang baik itu, antara lain: (1) validitas, yakni ketepatan atau kesesuaian, (2) reliabilitas, yakni dapat dipercaya, (3) objektivitas, yakni hasil tes dari seorang anak diperiksa oleh siapapun hasilnya akan sama.

Sejalan dengan pendapat Joni (1984:34) menyatakan bahwa adapun ciri- ciri yang harus dimiliki oleh suatu tes agar bisa menunaikan fungsinya sebagaimana diharapkan adalah validitas, reliabilitas, tingkat kesukaran, kemampuan diskriminasi dan syarat-syarat tambahan lain-lainnya seperti keluasan ruang lingkup, kemudahan administrasi serta skoring dan lain-lain. Misalkan, dalam tes mata pelajaran bahasa Indonesia harus memiliki validitas yang berarti kesesuaian antara perihal materi dalam kurikulum yang telah diajarkan dan hasil siswa dalam belajar mata pelajaran bahasa Indonesia, reliabilitas yang berarti apabila tes tersebut digunakan oleh guru untuk menguji siswa lain atau kelas lain, maka hasil yang diperoleh memiliki hasil yang sama sesuai dengan kemampuan masing-masing siswa, dan objektivitas yang berati bersifat adil tanpa dipengaruhi pandangan guru.

Penelitian sejenis yang telah dilakukan, berjudul Validitas Isi dan Konstruk Soal-Soal Ujian Nasional SMP Mata Pelajaran Bahasa Indonesia Tahun Ajaran 2011/2012 tahun 2013 oleh Hardika Fahruzzaman. Bahasan penelitian ini tentang soal ujian nasional SMP Mata Pelajaran Bahasa Indonesia memiliki validitas isi dan konstruk yang tinggi. Pada tahun 2014, penelitian berjudul Analisis Soal Ujian Akhir Semester (UAS) Mata Pelajaran Bahasa Indonesia Kelas VI MI Miftahul Astar Desa Dawung Bedug Kecamatan Ngadiluwih Kabupaten Kediri Tahun Ajaran 2012/2013 oleh Siti Winarsih, temuan penelitian ini adalah

\footnotetext{
"Corresponding author.

E-mail addresses: deanaputrikurniawan@gmail.com (Gustiana Putri Endah)
}

ISSN : 2579-3799 (Online) - BASINDO : Jurnal Kajian Bahasa, Sastra Indonesia, dan Pembelajarannya is licensed under Creative Commons Attribution-ShareAlike 4.0 International License (http://creativecommons.org/licenses/BY/4.0/).

48 | BASINDO : Jurnal Kajian Bahasa, Sastra Indonesia, dan Pembelajarannya 
soal ujian akhir semester Mata Pelajaran Bahasa Indonesia kelas VI MI Miftahul Astar memiliki ketepatan butir soal yang tinggi.

Temuan baru pada penelitian ini berdasarkan kualitas soal ujian akhir semester I mata pelajaran Bahasa Indonesia kelas XII SMA Negeri 1 Krian. Kualitas soal difokuskan pada kesesuaian validitas isi, kesesuaian validitas kostruk, dan kesesuaian soal pilihan ganda berdasarkan kaidah penulisan soal pilihan ganda.

\section{METODE}

Penelitian ini menggunakan pendekatan evaluatif. Pendekatan evaluative adalah penelitian yang bermaksud untuk mengumpulkan data tentang implementasi kebijakan (Arikunto, 2010: 37). Pendekatan ini dipilih karena pada kenyataannya yang diamati adalah untuk mengetahui validitas dan kualitas soal ujian akhir semester I Mata Pelajaran Bahasa Indonesia. Desain penelitian ini adalah deskriptif, sebab objek yang diamati masalah yang terjadi pada saat ini dan peneliti berusaha untuk mendeskripsikan situasi atau kejadian sesuai dengan kenyataan sebenarnya. Data berupa deskripsi verbal analisis soal dari objek penelitian, yaitu soal ujian akhir semester I kelas XII mata pelajaran Bahasa Indonesia Kelas XII SMAN 1 Krian.

Data penelitian berupa kisi-kisi soal dan soal ujian akhir semester I kelas XII SMAN 1 Krian. Instrumen pemandu yang akan memudahkan peneliti dalam proses identifikasi, klasifikasi, dan analisis soal ada 3 instrumen. Pertama, instrumen validitas isi soal ujian akhir semester berisi kolom nomor soal, kompetensi dasar, indikator pencapaian kompetensi, indikator soal, dan validitas kategori valid dan tidak valid. Kedua, instrumen validitas konstruk soal ujian akhir semester berisi kolom nomor soal, kompetensi dasar, indikator pencapaian kompetensi, indikator soal, materi (teks), pokok soal, pilihan jawaban, dan validitas kategori valid dan tidak valid. Ketiga, tabel analisis kesuaian soal ujian akhir semester dengan kaidah penulisan soal. Instrumen analisis kesesuaian soal ujian akhir semester berisi kolom nomor soal, materi pokok, kriteria soal, dan keterangan. Kemudian, untuk menentukan kriteria validitas isi, validitas konstruk, dan kesesuaian soal ujian pilihan ganda dengan kaidah penulisan soal pilihan ganda menggunakan kadar korelasi 0,80 - 1,00 Tinggi; 0,60 - 0,79 Lumayan tinggi; 0,40 - 0,59 Sedang; 0,20 - 0,39 Rendah; 0,00 - 0,19 Dapat diabaikan. Menurut Djiwandono (2008: 167-168) angka-angka yang bersifat kuantitatif itu dapat diberi label kualitatif yang menunjukkan tinggi rendahnya tingkat korelasi.

Pengumpulan data melalui dokumentasi, dengan cara mengumpulkan dokumen berupa kisi-kisi dan soal ujian akhir semester I kelas XII yang diperoleh dari SMAN 1. Teknik analisis yang digunakan pada penelitian ini terdiri atas identifikasi data, klasifikasi data, dan simpulan data. Pengecekan keabsahan data penelitian ini menggunakan triangulasi peneliti.

\section{HASIL}

Soal ujian akhir semester I mata pelajaran Bahasa Indonesia kelas XII SMAN 1 Krian memiliki kualitas lumayan tinggi dari segi kesesuaian validitas isi, kesesuaian validitas konstruk, dan kesesuaian penulisan soal pilihan ganda dengan kidah penulisan soal pilihan ganda. Validitas Isi Soal Ujian Akhir Semester I Mata Pelajaran Bahasa Indonesia Kelas XII.

Diketahui bahwa validitas isi soal ujian akhir semester I mata pelajaran bahasa Indonesia kelas XII SMA Negeri 1 Krian dapat ditinjau dari kesesuaian kompetensi dasar dengan indikator pencapaian dan indikator soal. Di dalam soal ini, ditemukan dari lima puluh butir soal pilihan ganda yang disajikan terdapat tiga puluh lima butir soal valid dan lima belas butir soal tidak valid. Hal ini dapat dilihat dari kesesuaian kompetensi dasar yang terdapat dalam kurikulum 2013, indikator pencapaian yang ditulis oleh guru, dan indikator soal, yang telah disusun oleh guru mata pelajaran dalam proses penulisan soal ujian.

Berdasarkan analisis validitas isi kesesuaian kompetensi dasar dengan indikator pencapaian dan indikator soal diketahui bahwa soal ujian akhir semester I mata pelajaran bahasa Indonesia kelas XII ditemukan tiga kompetensi dasar yang terdapat dalam kurikulum, yakni kompetensi 3.1 berbunyi memahami struktur dan kaidah teks cerita sejarah, berita, iklan, editorial/opini, dan cerita fiksi dalam novel baik lisan maupun tulisan, kompetensi 3.3 berbunyi menganalisis teks cerita sejarah, iklan, editorial/opini, dan cerita fiksi dalam novel baik lisan maupun tulisan, dan kompetensi 4.1 berbunyi menginterpretasikan makna teks cerita sejarah, berita, iklan, editorial/opini, dan cerita fiksi dalam novel baik lisan maupun tulisan.

Kompetensi 3.1 ditemukan tiga puluh enam butir soal. Jumlah tersebut, dua puluh tujuh butir soal diantaranya valid dan sembilan butir soal diantaranya tidak valid. Kompetensi 3.3 ditemukan satu butir soal. Kesesuaian kompetensi dasar dengan indikator pencapaian dan indikator soal butir soal ini valid. Kompetensi 4.1 ditemukan tiga belas butir soal. Jumlah tersebut, tujuh butir soal diantaranya valid dan enam butir soal tidak valid. 
Validitas Konstruk Soal Ujian Akhir Semester I Mata Pelajaran Bahasa Indonesia Kelas XII. Diketahui bahwa validitas konstruk soal ujian akhir semester I mata pelajaran bahasa Indonesia kelas XII SMA Negeri 1 Krian memiliki kualitas lumayan tinggi ditinjau dari kesesuaian kompetensi dasar, indikator pencapaian kompetensi, indikator soal, materi (teks), pokok soal, dan pilihan jawaban. Di dalam soal ini, ditemukan dari lima puluh butir soal pilihan ganda yang disajikan terdapat tiga puluh butir soal valid dan dua puluh butir soal tidak valid. Hal ini dapat dilihat dari kesesuaian kompetensi dasar, indikator pencapaian, dan indikator soal dengan materi (teks), pokok soal, dan pilihan jawaban.

Analisis validitas konstruk adalah penyelidikan yang dilakukan terhadap soal ujian akhir semester mata pelajaran bahasa Indonesia kelas XII untuk mencari bukti tentang kesesuaian perwujudan butir soal dari kompetensi yang terdapat dalam kurikulum bahasa Indonesia kelas XII semester satu. Analisis ini dilihat dengan mengidentifikasi indikator pencapaian kompetensi dan indikator soal dengan materi dan pokok soal serta pilihan jawaban dalam soal.

Kompetensi dasar 3.1 pada kurikulum yang berbunyi memahami struktur dan kaidah teks cerita sejarah, berita, iklan, editorial/opini, dan novel baik melalui lisan maupun tulisan, dalam soal ujian akhir semester mata pelajaran bahasa Indonesia kelas XII diklasifikasikan menjadi beberapa kompetensi. Kompetensi tersebut meliputi memahami struktur teks berita, memahami isi teks berita, memahami kaidah atau ciri kebahasaan teks berita, memahami kaidah atau ciri kebahasaan teks editorial, memahami kaidah atau ciri kebahasaan teks iklan, memahami kaidah atau ciri kebahasaan teks cerita sejarah, memahami kaidah atau ciri kebahasaan teks deskripsi, memahami kaidah atau ciri kebahasaan surat lamaran pekerjaan, memahami kaidah atau ciri kebahasaan teks tajuk rencana berita, memahami isi teks berita iklan penawaran, memahami kaidah/ciri kebahasaan kalimat berimbuhan, memahami isi teks cerita sejarah/biografi, dan memahami isi teks editorial.

Kompetensi 3.3 pada kurikulum yang berbunyi menganalisis teks cerita sejarah, berita, iklan, editorial/opini, dan novel baik melalui lisan maupun tulisan, dalam soal ujian akhir semester mata pelajaran bahasa Indonesia kelas XII diklasifikasikan menjadi satu kompetensi, yakni menganalisis teks berita. Kemudian, dirumuskan dalam indikator pencapaian siswa dapat menentukan kalimat tanya yang tepat sesuai dengan kutipan.

Kompetensi 4.1 pada kurikulum yang berbunyi menginterpretasi makna teks cerita sejarah, berita, iklan, editorial/opini, dan novel baik secara lisan maupun tulisan, dalam soal ujian akhir semester mata pelajaran bahasa Indonesia kelas XII diklasifikasikan menjadi beberapa kompetensi. Kompetensi tersebut meliputi menafsirkan isi teks paragraf eksposisi, menafsirkan isi teks editorial, menafsirkan isi teks berita, menafsirkan isi teks tajuk rencana, dan menafsirkan isi teks cerita sejarah atau biografi. Pada kompetensi ini ditemukan kompetensi dasar dengan indikator soal yang tidak valid. Kesesuaian Penulisan Soal Ujian Akhir Semester I Mata Pelajaran Bahasa Indonesia Kelas XII Berdasarkan Kaidah Soal Pilihan Ganda.

Dalam menulis soal pilihan ganda harus memperhatikan kaidah-kaidah sebagai berikut (Balitbang, 2007: 13-14). Kategori pertama, yakni materi meliputi: (a) soal harus sesuai dengan indikator, (b) pilihan jawaban harus homogen dan logis ditinjau dari segi materi, (c) setiap soal harus mempunyai satu jawaban yang benar atau yang paling benar. Kategori kedua, yakni konstruksi meliputi: (d) pokok soal harus dirumuskan secara jelas dan tegas, (e) rumusan pokok soal dan pilihan jawaban harus merupakan pernyataan yang diperlukan saja, (f) pokok soal jangan memberi petunjuk ke arah jawaban benar, (g) pokok soal jangan mengandung pernyataan yang bersifat negatif ganda, (h) panjang rumusan pilihan jawaban harus relatif sama, (i) pilihan jawaban jangan mengandung pernyataan, "Semua pilihan jawaban di atas salah", atau "Semua pilihan jawaban di atas benar", (j) pilihan jawaban yang berbentuk angka atau waktu harus disusun berdasarkan urutan besar kecilnya nilai angka tersebut, atau kronologisnya, (k) gambar, grafik, tabel, diagram, dan sejenisnya yang terdapat pada soal harus jelas dan berfungsi, dan (l) butir soal jangan bergantung pada jawaban soal sebelumnya.

Kategori ketiga, yakni bahasa meliputi: $(\mathrm{m})$ setiap soal harus menggunakan bahasa yang sesuai dengan kaidah bahasa Indonesia, (n) tidak menggunakan bahasa yang berlaku setempat, jika soal akan digunakan untuk daerah lain atau nasional, (o) setiap soal harus menggunakan bahasa yang komunikatif, dan (p) pilihan jawaban jangan mengulang kata atau frase yang bukan merupakan satu kesatuan pengertian.

Diketahui bahwa kesesuaian butir soal ujian akhir semester mata pelajaran bahasa Indonesia kelas XII dengan kaidah penulisan soal yang baik. Ditemukan 35 soal dari 50 soal yang sesuai dengan ketiga kategori penyusunan soal pilihan ganda, lengkap. Sisanya, 15 soal tidak sesuai dengan kaidah penulisan soal pilihan ganda. Dari 15 soal yang tidak sesuai itu dipilah menjadi tiga golongan. Golongan pertama, soal yang belum memenuhi salah satu atau lebih dari kategori pertama. Golongan kedua, soal yang belum memenuhi salah satu atau lebih dari kategori kedua. Golongan ketiga, soal yang belum memenuhi salah satu atau lebih dari kategori pertama dan kedua. 
Ditemukan 4 soal dari 15 soal yang tidak sesuai dengan kaidah penyusunan soal pada kategori materi. Dari tiga kaidah hanya satu yang tidak dipenuhi, yakni kaidah pertama yang berbunyi soal harus sesuai dengan indikator. Dua kaidah yang dipenuhi, yakni kaidah kedua yang berbunyi pilihan jawaban harus homogen dan logis ditinjau dari segi materi, dan kaidah ketiga yang berbunyi setiap soal harus mempunyai satu jawaban yang benar atau yang paling benar.

Ditemukan 9 soal dari 15 soal yang tidak sesuai dengan kaidah penyusunan soal pada kategori konstruksi. Sembilan kaidah dalam kategori ini ada empat yang tidak dipenuhi, yakni kaidah pertama berbunyi pokok soal harus dirumuskan secara jelas, kaidah kedua berbunyi rumusan pokok soal dan pilihan jawaban harus merupakan penyataan yang diperlukan saja, kaidah ketiga berbunyi pokok soal jangan memberi petunjuk ke arah jawaban benar, dan kaidah kelima berbunyi panjang rumusan pilihan jawaban harus relatif sama.

Ditemukan 2 dari 15 soal yang tidak sesuai dengan kaidah penyusunan soal pada kategori materi dan kategori konstruk. Pada kategori materi, tiga kaidah dalam kategori ini hanya satu yang tidak dipenuhi, yakni kaidah pertama berbunyi soal harus sesuai dengan indikator. Kemudian, pada kategori konstruksi, sembilan kaidah dalam kategori ini hanya satu yang tidak dipenuhi, yakni kaidah kesembilan berbunyi butir soal jangan bergantung pada jawaban soal sebelumnya.

\section{PEMBAHASAN}

Validitas Isi Soal Ujian Akhir Semester I Mata Pelajaran Bahasa Indonesia Kelas XII Validitas isi yang diteliti fokus pada tiga hal, yaitu kompetensi dasar, indikator pencapaian kompetensi, dan indikator soal. Ketiga hal tersebut harus berkaitan dan sesuai dengan kurikulum yang digunakan, yakni Kurikulum 2013. Tes dikatakan sahih jika sesuai dengan kemampuan dasar, materi pembelajaran, dan indikator dalam kurikulum (Basuki, 2010:14). Validitas isi bertujuan mampu mengungkapkan isi dalam kurikulum (Harsiati, 2011:96). Butir kisi-kisi soal ujian akhir semester I mata pelajaran Bahasa Indonesia kelas XII SMA 1 Krian pada kompetensi dasar 3.1 dan 3.3 mencerminkan memahami struktur, kaidah kebahasaan, dan analisis, sedangkan pada kompetensi dasar 4.1 mencerminkan interpretasi makna teks cerita sejarah, teks berita, dan teks editorial/topik. Menurut Sri dan Ibrahim (2012:86) validitas isi adalah ketepatan suatu alat ukur ditinjau dari isi alat ukur tersebut.

Kisi-kisi soal dengan nomor 34 dengan kata kunci dalam soal "menentukan reorientasi teks", siswa dituntut untuk mengetahui struktur, memahami pengertian dari masing-masing struktur, dan menentukan struktur tentang teks yang diujikan. Dapat dilihat bahwa kisi-kisi yang dituliskan mencerminkan kompetensi dasar 3.1 yang berisi memahami struktur dan kaidah teks cerita sejarah, berita, iklan, editorial/opini, dan novel baik melalui tulisan maupun lisan. Kemudian, dapat disimpulkan bahwa kisi-kisi soal ini terbukti memiliki kesesuaian dengan butir dalam kurikulum. Kisi-kisi soal dengan nomor 33 dengan kata kunci dalam soal "memahami", siswa dituntut untuk memahami teks berita dalam teks yang diujikan. Hal ini mengarahkan siswa agar mampu menentukan makna istilah yang terdapat dalam teks dengan tepat. Oleh sebab itu, siswa harus memahami dan mengerti isi teks berita yang disajikan.

Kompetensi dasar berikutnya adalah kompetensi dasar 3.3 tentang menganalisis teks. Kompetensi dasar ini tercermin pada salah satu butir soal nomor 1, siswa dituntut untuk memahami, mengerti, dan mengklasifikasikan tentang kalimat tanya $(5 \mathrm{~W}+1 \mathrm{H})$ dalam materi teks yang telah dipelajari dan diujikan.

Butir dalam Kurikulum berupa kompetensi dasar 3.1 berbunyi memahami struktur teks cerita sejarah, berita, iklan, editorial/opini, dan novel baik melalui lisan maupun tulisan, dan kompetensi dasar 3.3 berbunyi menganalisis teks cerita sejarah, berita, iklan, editorial/opini, dan novel baik melalui lisan mupun tulisan. Dapat dikatakan, butir kisi-kisi soal ujian sesuai dengan butir dalam kurikulum yang berlaku. Menurut Supranata (2005:51) validitas isi sering pula dinamakan validitas kurikulum yang berarti bahwa suatu alat ukur dapat dikatakan valid apabila sesuai dengan isi kurikulum yang akan diukur.

Kisi-kisi soal dengan nomor 31, siswa dituntut untuk mengetahui dan mampu menjelaskan tentang kaidah kebahasaan yang digunakan dalam teks cerita sejarah. Misal, butir kisi-kisi soal kode ini yakni menentukan tiga kalimat fakta. Dapat diartikan, siswa dituntut untuk mampu memberikan penjelasan tentang kaidah kebahasaan yang terdapat dalam teks cerita sejarah. Tuntutan ini sesuai dengan kompetensi 4.1 berbunyi menginterpretasi makna teks cerita sejarah, berita, iklan, editorial/opini, dan novel baik lisan maupun tulisan. Kisi-kisi soal dengan nomor 37, siswa dituntut untuk mampu menentukan isi teks berita yang telah dipelajari sehingga dapat menentukan masalah yang terdapat dalam teks berita. Sedangkan, kisi-kisi soal dengan nomor 6, siswa dituntut untuk mampu menjelaskan tentang teks editorial/opini dari segi pandangan penulis atau opini penulis teks editorisl/opini yang diasajikan dalam teks ujian. 


\section{Validitas Konstruk Soal Ujian Akhir Semester I Mata Pelajaran Bahasa Indonesia Kelas XII}

Berdasarkan hasil penelitian, validitas konstruk yang diteliti fokus pada kesesuaian indikator pencapaian dan indikator soal dengan materi dan pokok soal ujian akhir semester I mata pelajaran Bahasa Indonesia kelas XII. Syarat soal ujian memiliki validitas konstruk yang tinggi, adanya indikator dari setiap konsep butir soal. Konstruk dijabarkan menjadi indikator-indikator esensial yang sesuai. Butir-butir soal harus disusun untuk masing-masing indikator (Harsiati, 2011:98). Berdasarkan hasil analisis, soal ujian akhir semester I mata pelajaran Bahasa Indonesia kelas XII muncul bukti-bukti kesesuaian validitas konstruk dari segi kesesuaian indikator pencapaian dengan butir soal ujian. Indikator harus lengkap sehingga dapat mengukur konsep materi secara utuh (Harsiati, 2011:98).

Soal dengan nomor 11, butir soal ini terbukti dengan indikator soal. Dilihat melalui indikator pencapaian, yakni siswa dapat menentukan tahapan peristiwa dengan tepat. Kemudian, diwujudkan dalam butir soal, yakni tahapan peristiwa yang tepat dalam soal yang telah disajikan.

Soal dengan nomor 13, butir soal kode ini membahas tentang menentukan kutipan teks berita yang terdapat dalam dalam soal. Soal ini mencerminkan indikator pencapaian kompetensi. Indikator pencapaian kompetensi yang berisi siswa dapat isi teks berita yang terdapat dalam teks dengan tepat. Indikator ini juga mencerminkan kompetensi dasar, yakni menginterpretasikan makna teks cerita sejarah, berita, iklan, editorial/opini, dan cerita fiksi dalam novel baik lisan maupun tulisan. Apabila bentuk tugas mendekati perilaku yang sebenarnya yang akan diukur, maka hasil pengukuran tersebut dapat dikatakan memiliki validitas konstruk (Ainin, 2006:25). Maka, syarat validitas konstruk yang utama adalah setiap soal ujian yang disusun harus memiliki indikator soal yang lengkap dan jelas.

Soal dengan nomor 18, butir soal kode ini membahas tentang siswa yang dituntut untuk mampu memilih kalimat yang menyatakan keterangan tempat yang terdapat dalam paragraf dalam soal yang telah disajikan. Butir soal ini sesuai dengan indikator pencapaian, yakni siswa dapat menentukan kalimat yang yang memiliki keterangan tujuan dengan tepat.

Soal dengan nomor 23, butir soal sesuai dengan indikator soal. Hal ini, terbukti dari kesesuaian butir soal yang membahas tentang fakta dalam wacana yang terdapat dalam butir soal yang disajikan. Kemudian, siswa dituntut untuk mampu menentukan orientasi teks berita yang terdapat dalam soal. Butir soal ini sesuai dengan indikator pencapaian, yakni siswa dapat menentukan struktur teks berita. Sejalan dengan Sudjana (2004:14-15) untuk menetapkan validitas konstruk pengertian adalah dengan melihat indikator-indikator dari setiap konsep yang berhubungan positif satu sama lain.

Soal dengan nomor 42, butir kode soal ini terbukti sesuai dengan indikator pencapaian. Butir soal dengan indikator pencapaian membahas tentang kaidah atau ciri kebahasaan teks yang telah disajikan dalam soal. Butir soal kode ini, siswa dituntut untuk mampu mengisi titik-titik kosong yang terdapat dalam paragraf pada soal menggunakan kalimat yang memiliki frasa adjektiva. Sesuai dengan indikator pencapaian, yakni siswa dapat menentukan kalimat yang beradjektiva dalam teks dengan tepat. Oleh karena itu, tes tertulis menuntut reespons dari peserta yang dapat dijadikan sebagai representasi dari kemampuan yang dimiliki (Permen nomor 53 Panduan Penilaian, 2015:15).

Soal dengan nomor 46, butir soal mencerminkan indikator soal serta sesuai dengan kompetensi dasar yang diukur. Inti butir soal kode ini membahas tentang sesuatu yang dapat diteladani dari tokoh yang terdapat dalam teks yang disajikan dalam soal tes. Butir soal inisesuai dengan indikator pencapaian, yakni siswa dapat menentukan kalimat berisikan keteladanan yang terdapat dalam teks dengan tepat.

\section{Kesesuaian Soal Ujian Akhir Semester Berdasarkan Kaidah Soal Pilihan Ganda}

Berdasarkan hasil analisis, soal ujian akhir semester I mata pelajaran Bahasa Indonesia kelas XII SMA 1 Krian berwujud soal pilihan ganda dan berjumlah lima puluh soal. Menurut Balitbang (2007: 13-14) dalam menulis soal pilihan ganda harus memerhatikan kaidah-kaidah sebagai berikut. Kategori pertama, yakni materi memiliki tiga kaidah. Kategori kedua, yakni konstruksi memiliki sembilan kaidah. Kategori ketiga, yakni bahasa memiliki empat kaidah.

Ditinjau dari kualitas soal berdasarkan kaidah soal pilihan ganda, dari lima puluh soal pilihan ganda muncul soal yang sesuai dan tidak sesuai dengan kaidah penulisan soal pilihan ganda. Soal pilihan ganda yang sesuai berjumlah tiga puluh lima soal dan soal pilihan ganda yang tidak sesuai berjumlah lima belas soal. Ketidaksesuaian dibedakan menjadi tiga golongan, yakni golongan pertama, golongan kedua, dan golongan ketiga.

Golongan pertama, yakni soal yang belum memenuhi salah satu atau lebih dari kategori pertama. Kategori pertama dalam kaidah soal, yakni kategori materi. Kategori materi meliputi tiga kaidah, yakni (a) soal harus sesuai dengan indikator; (b) pilihan jawaban harus homogen dan logis ditinjau dari segi materi; dan (c) setiap soal harus mempunyai satu jawaban yang benar atau yang paling benar. Ada empat soal dalam golongan pertama, yakni soal dengan nomor 27), 28), 32), dan 33). Keempat soal tersebut hanya 
memenuhi satu kaidah dari tiga kaidah yang harus dipenuhi. Kaidah yang tidak dipenuhi dari kategori materi, yakni kaidah (a) soal harus sesuai dengan indikator.

Golongan kedua, yakni soal yang belum memenuhi salah satu atau lebih dari kategori kedua. Kategori kedua dalam kaidah soal, yakni kategori konstruksi. Kategori konstruksi meliputi sembilan kaidah, yakni (d) pokok soal harus dirumuskan secara jelas dan tegas; (e) rumusan pokok soal dan pilihan jawaban harus merupakan pernyataan yang diperlukan saja; (f) pokok soal jangan member petunjuk ke arah jawaban benar; (g) pokok soal jangan mengandung pernyataan yang bersifat negatif ganda; (h) panjang rumusan pilihan jawaban harus relatif sama; (i) pilihan jawaban jangan mengandung unsur "semua pilihan jawaban di atas salah" atau "semua pilihan jawaban di atas benar"; (j) pilihan jawaban yang berbentuk angka atau waktu harus disusun berdasarkan urutan besar kecilnya nilai angka tersebut atau kronologisnya; (k) gambar, grafik, tabel, diagram, dan sejenisnya yang terdapat pada soal harus jelas dan berfungsi; (1) dan butir soal jangan bergantung pada jawaban soal sebelumnya.

Ada sembilan soal dalam golongan kedua, yakni soal dengan nomor1), 5),6), 16), 17), 18), 19), 45), dan 50). Sedangkan soal dengan nomor 45) dan 50) hanya memenuhi tujuh dari sembilan kaidah pada kategori konstruksi. Dua kaidah yang tidak dipenuhi, yakni kaidah (d) pokok soal harus dirumuskan secara jelas dan tegas, dan kaidah (e) rumusan pokok soal pilihan jawaban harus merupakan pernyataan yang diperlukan saja. Soal dengan nomor 6) hanya memenuhi tujuh dari sembilan kaidah pada kategori konstruksi. Dua kaidah yang tidak dipenuhi, yakni kaidah (f) pokok soal jangan member petunjuk ke arah jawaban benar dan kaidah (h) panjang rumusan pilihan jawaban harus relatif sama. Soal dengan nomor 16), 17),18), 19), 1), dan 5) hanya memenuhi delapan kaidah pada kategori konstruksi. Satu kaidah yang tidak dipenuhi, yakni kaidah (h) panjang rumusan pilihan jawaban harus relatif sama.

Golongan ketiga, yakni soal yang belum memenuhi salah satu atau lebih dari kategori pertama dan kedua. Ada dua soal dalam golongan ketiga, yakni soal dengan nomor 34) dan 35). Soal dengan nomor 34) dan 35) hanya memenuhi dua kaidah dari kategori pertama, memenuhi delapan kaidah dari kategori kedua, dan memenuhi empat kaidah dari kategori ketiga. Kaidah yang tidak dipenuhi dalam kategori pertama, yakni kaidah (a) soal harus sesuai dengan indikator. Kaidah yang tidak dipenuhi dalam kategori kedua, yakni kaidah (1) butir soal jangan bergantung pada jawaban soal sebelumnya.

\section{SIMPULAN}

Berdasarkan paparan hasil temuan beserta pembahasannya dari penelitian mengenai kualitas soal ujian akhir semester dari segi validitas isi, validitas konstruk, dan kesesuaian soal ujian dengan kaidah penulisan soal pilihan ganda sebagai berikut.

Pertama, validitas isi yang terdapat dalam soal ujian akhir semester I mata pelajaran Bahasa Indonesia kelas XII SMAN 1 Krian memiliki validitas lumayan tinggi. Hal ini membuktikan dari lima puluh butir soal yang telah disajikan, terdapat 35 butir soal dinyatakan valid dan 15 butir soal dinyatakan tidak valid.

Kedua, validitas konstruk yang terdapat dalam soal ujian akhir semester I mata pelajaran Bahasa Indonesia kelas XII SMAN 1 Krian memiliki validitas lumayan tinggi. Hal ini terbukti, dari lima puluh butir soal dinyatakan 30 butir soal dinyatakan valid dan 20 butir soal dinyatakan tidak valid.

Ketiga, kesesuaian soal ujian akhir semester I mata pelajaran Bahasa Indonesia kelas XII SMAN 1 Krian dengan kaidah penulisan soal pilihan ganda terbukti lumayan tinggi. Hal ini terbukti dengan sebanyak 35 butir soal dinyatakan valid dengan kriteria kaidah soal pilihan ganda dan 15 butir soal dinyatakan tidak valid dengan kriteria kaidah soal pilihan ganda.

\section{SARAN}

Berdasarkan hasil penelitian dan kesimpulan yang diperoleh, maka dikemukakan saran-saran yang dapat menjadi pertimbangan guru mata pelajaran Bahasa Indonesia, peneliti lanjutan, dan penyusun buku mata pelajaran Bahasa Indonesia untuk lebih memahami pentingnya validitas dan kualitas soal ujian. Bagi guru mata pelajaran Bahasa Indonesia, upaya proses ujian tulis merupakan tes yang dilakukan oleh guru kepada siswa yang bertujuan untuk mengetahui kemampuan penguasaan siswa terhadap proses belajar dan membuat keputusan mengenai pertimbangan kenaikan maupun kelulusan siswa. Oleh karena itu, dalam proses penyusunan soal ujian perlu memerhatikan kesesuaian kurikulum, kompetensi dasar, indikator pencapaian kompetensi, indikator soal, dan materi yang telah diajarkan kepada siswa sehingga soal tersebut berkualitas tinggi dari segi validitas isi, validitas konstruk, dan soal pilihan ganda yang bermutu. Bagi peneliti lanjutan, peneliti selanjutnya yang ingin mengadakan penelitian dengan topik yang sama, maka diharapkan dapat menggunakan objek penelitian yang berbeda. Misalnya, soal ujian tengah semester atau soal ujian praktik. Dapat pula menggunakan tingkat sekolah SMP dengan populasi siswa 
kelas VII, VIII, IX atau SMK kelas X dan XI yang sudah menggunakan Kurikulum 2013. Dapat juga daerah penelitian yang berbeda, seperti wilayah penelitiannya di sekolah lain, seperti di daerah ibu kota provinsi.

\section{DAFTAR RUJUKAN}

Ainin, M. (2006). Evaluasi dalam Pembelajaran Bahasa Arab. Malang: Misyikat.

Arikunto, S. (2010). Prosedur Penelitian: Suatu Pendekatan Praktik. Jakarta: Rineka Cipta.

Badan Penelitan dan Pengembangan. (2007). Panduan Penulisan Soal Pilihan Ganda. Jakarta: Depdiknas.

Basuki, I.A. (2010). Penilaian Keterampilan Berbahasa Indonesia. Malang: Universitas Negeri Malang.

Dikti. (2013). Peraturan Menteri Pendidikan dan Kebudayaan Republik Indonesia Nomor 81A Tahun 2013 Tentang Implementasi Kurikulum Pedoman Umum Pembelajaran. Jakarta: Kemendikbud.

Dikti. (2015). Peraturan Menteri Pendidikan Nasional No. 53 tahun 2015 tentang Panduan Penilaian untuk Sekolah Menengah Atas dan Sederajat. Jakarta: Kemendikbud.

Djiwandono, S. (2008). Tes Bahasa: Pegangan Bagi Pengajar Bahasa.Jakarta: PT Indeks.

Djiwandono, S. (1996). Tes Bahasa dalam Pengajaran. Bandung: Penerbit ITB.

Fahruzzaman, H. (2013). Validitas Isi dan Konstruk Soal-Soal Ujian Nasional SMP Mata Pelajaran Bahasa Indonesia Tahun Ajaran 2011/2012 tahun 2013. Skripsi tidak diterbitkan. Malang: Fakultas Sastra Universitas Negeri Malang.

Harsiati, T. (2011). Penilaian Dalam Pembelajaran: Aplikasi pada Pembelajaran Membaca dan Menulis. Malang: UM PRESS.

Sudjana, N. (2004). Penilaian Hasil Proses Belajar Mengajar. Bandung: PT Remaja Rosdakarya.

Sukardi. (2014). Evaluasi: Program Pendidikan dan Kepelatihan. Jakarta: PT Bumi Aksara.

Sugiyono. (2014). Metode Penelitian Kuantitaif, Kualitatif, Kualitatif, dan R\&D. Bandung: Alfabeta.

Sutomo. (1984). Teknik Penilaian Pendidikan. Bina Ilmu: Jakarta.

Supranata, S. (2005). Analisis, Validitas, Reliabilitas, dan Interpretasi Hasil Tes. Bandung: PT Remaja Rosdakarya Offset.

Wahyuni, S. dan Ibrahim. A.S. (2012). Asesmen Pembelajaran Bahasa. Bandung: Refika Aditama. 